\title{
Research collaboration for a knowledge- based economy: towards a conceptual framework
}

\author{
Mavis Serwah Benneh Mensah ${ }^{1 *}$ and Francis Enu-Kwesi ${ }^{2}$
}

\author{
* Correspondence: mmensah@ucc. \\ edu.gh \\ ${ }^{1}$ Centre for Entrepreneurship and \\ Small Enterprise Development \\ (CESED), School of Business, College \\ of Humanities and Legal Studies, \\ University of Cape Coast, Cape \\ Coast, Ghana \\ Full list of author information is \\ available at the end of the article
}

\begin{abstract}
A knowledge-based economy thrives on constructed advantages generated through well-planned recursive interactions among key actors in the economy. Using a desk review, this paper advances theoretical and conceptual arguments in support of research collaboration as a critical and viable medium for the conduct of research and innovation geared towards economic growth and development. We propose a conceptual framework to guide future research on the determinants and the dynamics of research collaboration as well as the use of collaborative research output in innovation. The framework, which can be modelled, is recommended for descriptive and explanatory research aimed at obtaining first-hand information for policy interventions that seek to advance the knowledge-based economy, through research collaboration.
\end{abstract}

Keywords: Collaboration, Economy, Innovation, Knowledge, Research

\section{摘 要}

知识经济基于由经济主要参与者之间的计划好了的递归相互作用生成的构建优 势而蓬勃发展。通过书面材料回顾,本文探索了支持研究合作的理论和概念之 争,提出面向经济增长和发展而进行研究与创新的紧要可行的方法。我们给出一 个概念框架来指导在研究合作的决定因素和动力方面的未来研究,还有合作研究 的成果在创新中的利用。这个可以建模的框架建议通过研究合作进行描述性和 解释性研究, 旨在为寻求推动知识经济的政策干预获取第一手信息。

\section{Résumé}

Une économie de la connaissance se nourrit d'avantages construits générés par des interactions récursives bien planifiées entre les principaux acteurs de l'économie. À partir d'une revue documentaire, cet article avance des arguments théoriques et conceptuels à l'appui de la collaboration en matière de recherche comme moyen critique et viable de mener des activités de recherche et d'innovation axées sur la croissance économique et le développement. Nous proposons un cadre conceptuel pouvant baliser des recherches ultérieures sur les déterminants et la dynamique de la collaboration en matière de recherche, ainsi que l'utilisation de résultats de recherche collaborative dans l'innovation. Le cadre, qui peut être modélisé, est recommandé pour (Continued on next page) 
(Continued from previous page)

la recherche descriptive et explicative visant à obtenir des informations de première main pour des interventions de politiques visant à faire progresser l'économie de la connaissance, grâce à la collaboration en matière de recherche.

\section{Resumo}

Uma economia baseada no conhecimento prospera em vantagens construídas geradas através de interações recursivas bem planejadas entre os principais atores da economia. Usando uma mesa revisão, este artigo avança argumentos teóricos e conceituais em apoio de colaboração de pesquisa como meio crítico e viável para a realização de pesquisas e inovação voltada para o crescimento econômico e o desenvolvimento. Propomos um quadro conceitual para orientar futuras pesquisas de forma que sejam determinantes e dinâmicas e colaborativas, bem como o uso da produção de pesquisa colaborativa em inovação. O quadro, que pode ser modelado, é recomendado por ser descritivo e por explorar as pesquisas destinadas a obter informações de primeira mão para intervenções políticas que buscam avançar a economia baseada no conhecimento, através da colaboração de pesquisa.

\section{Аннотация}

Экономика знаний успешна в структурах, основанных на систематическом взаимодействии ключевых участников экономических отношений. На основании кабинетных исследований в настоящей статье представлены теоретические и концептуальные аргументы в поддержку исследовательского партнерства как критически значимой и благоприятной среды для проведения исследований и инноваций, способствующей экономическому росту и развитию. Мы предлагаем концептуальную модель для использования в будущих исследованиях ключевых факторов и логики развития исследовательского партнерства, равно как и вклада совместных исследований в инновации. Концепция, которая может быть представлена в виде модели, рекомендована для описательных и пояснительных исследований, нацеленных на получение первичной информации при разработке стратегий в сфере стимулирования экономики знаний посредством исследовательского партнерства.

\section{Resumen}

Una economía basada en el conocimiento se nutre de las ventajas generadas a través de interacciones recursivas entre los principales actores de la economía. Este documento presenta argumentos teóricos y conceptuales en apoyo de la investigación colaborativa como un medio crítico y viable para la investigación e innovación orientadas al crecimiento económico y el desarrollo. Proponemos un marco conceptual para orientar la investigación futura sobre los determinantes y la dinámica de la investigación colaborativa, así como el uso sus resultados en el proceso de innovación. Este marco conceptual, que es susceptible de modelación, se recomienda para la investigación descriptiva y explicativa de las intervenciones de políticas que promuevan la investigación colaborativa como un instrumento de política económica.

\section{Multilingual abstract}

Please see Additional file 1 for translation of the abstract into Arabic. 


\section{Introduction}

Research and innovation have been well established in theory and in practice as critical drivers of economic growth and development (Acs et al. 2009; Schumpeter 1983). However, mere investment in research or knowledge production or increase in research and development ( $R$ \& D) expenditures does not automatically translate into competitive innovations, unless the various activities are accompanied by entrepreneurship that is carried out through networks or well-planned recursive interactions such as research collaboration (Braunerhjelm et al. 2010; Block et al. 2013).

Research collaboration involves interaction among persons and or entities of diverse interests to embark upon research and to use the research findings for pre-determined purposes such as advancing knowledge in a scientific field and or innovation (Baba et al. 2009; Teirlinck and Spithoven 2013). It can take different forms including businessbusiness research collaboration (Teirlinck and Spithoven 2013), university-industry research collaboration (Cunningham and Link 2015), international research collaboration (Melber 2015) and research collaboration among researchers in the same, or from different, academic disciplines, universities or national research institutes (Bellotti et al. 2016). Particularly important, to the advancement of the knowledge-based economy, is research collaboration that is driven by a national research and innovation agenda and supported by the right national and institutional structures, systems and incentives (Etzkowitz 2003; Leahey 2016).

The knowledge-based economy is an economy in which knowledge drives economic growth and development; hence, great investments are made in research, innovation and human and social capital (Etzkowitz 2003; Rinne and Koivula 2005). Cooke and Leydesdorff (2006) distinguish the knowledge-based economy from a knowledge economy by indicating that the knowledge economy focuses on the composition of the labour force while the knowledge-based economy thrives on a constructed advantage, from technological trajectories and regimes, which emanate from interfacing economic development on a systems perspective. Leydesdorff (2010) further argues that a knowledge-based economy is analytically different from a knowledge economy in that in the former, codified knowledge is regarded as key to economic growth and development, while in the latter, emphasis is placed on knowledge workers, and hence tacit or embodied knowledge.

The differences notwithstanding, research collaboration facilitates knowledge acquisition for enhanced performance and or innovation in economies that invest in it, particularly university-industry research collaboration (Acs et al. 2009; Cunningham and Link 2015). For instance, Cunningham and Link (2015), in a study of universityindustry R \& D collaborations in European Union countries, acknowledge the universal role of research collaboration as a dimension of entrepreneurial activity and an important driver of economic growth and development. This economic role of research collaboration is made possible due to the inherent capacity of collaboration to act as a vehicle for the exchange of tacit knowledge which, although is fundamental to innovation, cannot be openly traded on the market without the holder of the knowledge being part of the knowledge exchange process (Johnson et al. 2002; Karnani 2013).

In recognition of the role of research collaboration in the knowledge-based economy, research collaboration has been studied from several angles including types of collaboration such as university-industry research collaboration and international research 
collaboration (Perkmann and Walsh 2009; Melber 2015), collaborating partners (Hughes et al. 2011; Hughes and Kitson 2012), determinants (Hu et al. 2016), costs and benefits/purpose (Lee 2000; D'Este and Perkmann 2011) and economic impact (Robin and Schubert 2013; Cheah and Yu 2016). It is noteworthy that these previous studies have focused on one or few dimensions of research collaboration and have had to rely on one or a combination of relevant theories such as network theory and institutional theory. While appreciating the immense contributions that such studies have made to the field, it is imperative to note that there is still the need to bring the various dimensions of research collaboration into a holistic perspective for further research and policy attention, particularly where research collaboration is a crucial aspect of a nation's economic development strategy.

Hence, this paper relies on several theories as it attempts to provide a broader perspective on research collaboration, with some recommendations for empirical research. Thus, on the basis of selected psychosocial, research, innovation and social capital theories and models, specifically the knowledge spillover theory of entrepreneurship (Acs et al. 2013), the theory of economic development (Schumpeter 1983), the theory of planned behaviour (Ajzen 2011) and the network theory of social capital (Lin 2008), we seek to contribute to the evolving field by proposing a conceptual framework of research collaboration for a knowledge-based economy. The paper takes a step backwards, by situating the subject matter within a broader theoretical framework and in so doing, proffers a conceptual framework that systematically integrates and highlights critical dimensions of innovationdriven research collaboration for further empirical research and policy considerations.

The rest of the paper highlights the theoretical underpinnings of key arguments in the paper and discussion of the proposed framework, with an analysis of key examples to illustrate the framework. The paper ends with recommendations for empirical test of the proposed conceptual framework, conclusions and policy implications.

\section{Theoretical background}

In this section of the paper, we present the review of related literature on the meaning and importance of collaboration and research collaboration, actors of research collaboration and the essentials of research collaboration. We support key arguments of the review with theoretical insights from the theory of economic development by Schumpeter (1983), the theory of planned behaviour by Ajzen (1991), the network theory of social capital by Lin (1999) and the knowledge spillover theory of entrepreneurship by Acs et al. (2009).

\section{The concept of collaboration}

There is no one universally accepted definition of the concept of collaboration (Menya and K'akumu 2016). Nevertheless, Gray's (1985) scholarly work on collaboration has been a key reference point for the definition of collaboration, in a number of cases. For instance, Borden (1999) adopts Gray's (1985) definition which identifies collaboration as a medium for parties who see different aspects of a problem to constructively explore their differences and search for a collective solution to the problem. Similarly, McNamara (2012) makes reference to Gray's definition of collaboration and defines collaboration as an interaction between parties who work together to pursue complex goals based on shared interests and a collective responsibility for interconnected tasks which cannot be accomplished individually. 
Although collaboration is often made synonymous to co-operation, a definition of the latter by McNamara (2012) shows that in co-operation, parties interact to serve individual interests as against the pursuit of both collective and individual interests in collaboration (Hughes and Kitson 2012). According to McNamara (2012), co-operation refers to the interaction between participants with capabilities to accomplish organisational goals but who choose to work together to serve individual interests. Both collaboration and co-operation possess and thrive on some major characteristics which may explain why both terms are often used synonymously.

From a knowledge sharing perspective, Nissen et al. (2014) acknowledge co-operation and collaboration as occurring on a continuum of interaction and distinguish between the two forms of interaction by stressing on the existence of relatively stronger linkages and high level of trust and knowledge sharing between collaborating partners. Discussions on collaboration by Borden (1999) and Mayer and Kenter (2015) identify diverse stakeholders, communication, shared goals and resources, consensus building, social capital and trust as some of the primary components of collaboration. Collaboration may take place for several reasons including the quest to seek and use/share resources, pursue shared goals and gain synergistic rewards (Nyaga et al. 2013).

Collaboration could be dyadic or network-based. Research shows that dyadic collaboration involves two actors who may share similar or disproportional power relationships, for instance as examined by Nyaga et al. (2013) in a study of power asymmetry, adaptation and collaboration in dyadic relationships involving a powerful partner. Network collaboration, on the other hand, goes beyond interactions between two actors and emerges on the basis of triadic closure whereby two nodes that are indirectly connected have the tendency to form a link (Bergé 2017). Bergé (2017) cites higher propensity of trust, enforcement of sanctions and conflict mitigation as some of the advantages that are peculiar to triadic linkages which become feasible as a result of reduction in individual power with the transition from a dyadic interaction to a network-based interaction.

Collaboration, irrespective of kind, is a fundamental characteristic of human societies. It can take place at the micro level among members of a group, an organisation or society (see for example a study of the evolution of research collaboration across disciplines by Bellotti et al. 2016) or at the macro level among actors/stakeholders and sectors within a society or an economic system (Cunningham and Link 2015). The knowledge-based economy is one economic system that thrives on collaboration among its key actors. The next section of the review takes a look at research collaboration and its importance in the knowledge-based economy.

\section{Importance of research collaboration in the knowledge-based economy}

Drawing upon the preceding discussions on collaboration and co-operation as well as studies on research collaboration (e.g. Baba et al. 2009; Teirlinck and Spithoven 2013), we define research collaboration as interaction among persons and or entities of diverse interests to embark upon research and to use the research findings for pre-determined purposes such as advancing knowledge in a scientific field and or innovation. Research collaboration constitutes an integral part of the knowledge-based economy by serving as a medium for the production and exchange or spillover of tacit knowledge between knowledge producers and knowledge users (Cooke and Leydesdorff 2006; Leydesdorff 2012). 
This is made possible as a result of the capacity of research collaboration to bring the productive spheres of research and innovation into an interactive mode thereby ensuring that tacit knowledge is harnessed for growth and development purposes.

Tacit knowledge, as explained by Johnson et al. (2002), is that aspect of knowledge which is embedded in its holder, offers the holder competitive advantage and cannot be easily transferred or exchanged without the holder being part of the transfer process. Thus, in contrast to codified knowledge which is represented in writing or symbols and is often openly available to potential users (Karnani 2013), tacit knowledge is not easily accessible due to its nature and the unique advantage(s) it offers. As a result, Johnson et al. (2002) note that the tacit dimension of knowledge makes interaction or collaboration, as opposed to publication, the ideal medium for the transfer of the knowledge from incumbents to users. Collaboration, therefore, contributes towards consensus building on the terms and rewards of knowledge production and usage and helps to bridge the knowledge filter which Acs et al. (2013) describe as the gap that exists when investment in knowledge creation yields new knowledge that is yet to be exploited and put to commercial use.

The knowledge spillover theory of entrepreneurship emphasise the importance of intra-temporal spillover of tacit knowledge within an economy (Acs et al. 2009). According to the theory, for knowledge or research output to contribute to innovation, and hence to economic growth, it must serve as possible sources of entrepreneurial opportunities by moving from knowledge producers to knowledge users, particularly to entrepreneurial start-ups, otherwise the economy will not make significant gains from knowledge production (Acs et al. 2013). Thus, the nature of tacit knowledge and the importance of the knowledge to innovation make collaboration indispensable to the capacity of research and innovation to effectively and efficiently function as drivers of economic growth and development.

Therefore, contrary to endogenous growth frameworks which do not explicitly link entrepreneurship to investment in new knowledge and knowledge spillover, the knowledge spillover theory of entrepreneurship illustrates entrepreneurship as a key mechanism that may enhance the effect of knowledge investments in an economy (Acs et al. 2009; Braunerhjelm et al. 2010), hence making it necessary for the promotion of research collaboration as a pedestal for research and innovation from an entrepreneurial purview. From the perspective of the knowledge spillover argument and research collaboration, it is inferable that at the broader level, knowledge producers are primarily involved in creativity, while knowledge users mainly engage in innovation, two key activities that constitute entrepreneurship. Generally, whereas creativity comprises the mental process of idea generation, innovation involves the application of the creative ideas to solving problems (Barringer and Ireland 2008) thereby depicting division of labour in the economy.

The need for division of labour was also stressed by Schumpeter (1983) in his theory of economic development in addition to other pre-requisites such as private property and free competition. In the face of division of labour in the knowledge-based economy, research collaboration offers knowledge producers and users the opportunity to commit to a common research and innovation agenda with the hope of generating knowledge and facilitating learning for effective economic performance and or the development of competitive innovations that will drive economic growth and development. On the premise 
that division of labour thrives on closer and recursive interactions among key economic agents, the next section of the review takes a look at the actors of research collaboration.

\section{Roles and actors in research collaboration}

Research collaboration involves several roles which are performed by specific actors. Some of the principal roles are agenda setting, provision of resources such as funding and infrastructure, knowledge production through research, and knowledge usage which can take the form of adaptation for enlightenment and or application to problem solving or innovation (Perkmann and Walsh 2009; Teirlinck and Spithoven 2013). Research in the field shows that businesses/industry players, communities, governments, universities, research institutions and non-governmental organisations are some of the actors that engage in research collaboration.

Therefore, from the perspective of parties to research collaboration, one can identify various forms of research collaboration such as business-business research collaboration (Teirlinck and Spithoven 2013), university-industry-government research collaboration (Park and Leydesdorff 2010), university-industry research collaboration (Cunningham and Link 2015), international research collaboration (Melber 2015) and research collaboration among researchers in the same, or from different, academic disciplines, universities or national research institutes (Bellotti et al. 2016). Besides these forms of research collaboration, Belderbos et al. (2015) identify various collaborating partners of firms to include customers, competitors, suppliers, research institutions and universities.

Generally, the various roles in research collaboration can be assumed by any stakeholder which is party to the collaboration. For example, in a study of government-university-industry relations in South Korea by Park and Leydesdorff (2010), the government set national agenda, incentives and structures, like the Ministry of Knowledge Economy, to promote the national system of innovation and to foster collaboration between industry and science with the university having the primary role of conducting research for uptake in innovation by industry players. On the other hand, a study by Perkmann and Walsh (2009) on university-industry research collaboration showed that in a number of instances, industry commissioned and financed the research project for both industry and university scientists to carry out joint research.

Although economic actors can assume any of the roles in research collaboration (Leydesdorff 2012), for the sake of efficiency and effectiveness, research collaboration within or for the attainment of a knowledge-based economy involves clear definition of roles for the principal actors in the economy. The roles include knowledge production/ research by the university and research institutions, innovation by industry and governance and regulation by the government (Etzkowitz and Leydesdorff 1995).

Various knowledge-based models acknowledge the importance of collaboration among stakeholders in the knowledge-based economy. For instance, the triple helix model of university-industry-government relations regards the university, industry and government or the state as the leading actors in the knowledge-based economy, and whose activities must be performed through recursive interactions such as research collaboration (Cheah and Yu 2016; Etzkowitz and Leydesdorff 1995). However, unlike the triple helix model, the quadruple helix concept while acknowledging the triple helix actors and their roles also considers civil society as an essential actor which can make 
critical input, such as definition of research problem and implementation of research findings, to collaborative projects (Afonso et al. 2012). The roles of the principal parties to research collaboration, in the knowledge-based economy, have been well articulated in literature.

From the perspective of the triple helix concept, Etzkowitz (2003) and Afonso et al. (2012) agree that in the recursive multi-organisational arrangements, universities are primarily expected to produce and exchange knowledge, through research, to augment their traditional knowledge production and dissemination functions such as publication, teaching and subsequent graduation of students into the workforce and the wider community. Industry, on the other hand, has the mandate to produce wealth by transforming the knowledge or research output from academia and research institutions into innovations and commercialising the innovations on the market (Etzkowitz and Leydesdorff 2000). Robin and Schubert (2013) acknowledge that interaction between industry and science, which serves as a pillar in the creation of a knowledge-based economy, is one of the most prominent institutional interfaces for knowledge diffusion and innovation. The government performs an oversight and supporting role by spearheading the development and implementation of proactive policies for the funding and promotion of research and innovation (Park and Leydesdorff 2010).

Research collaboration among the various actors in the knowledge-based economy has been found to yield positive results in terms of enhanced industrial performance and innovation. For example, a study by Davenport et al. (1998) in New Zealand established improved managerial ability and firm competitiveness as an essential impact of university-industry research collaboration. Another study by Robin and Schubert (2013) on research collaboration between firms and universities/public research institutions, in Germany and in France, found that the collaboration had a significant positive influence on product and process innovation intensity of firms. However, the impact was twice as high in Germany as the impact in France. Drawing on a comparison of institutional context of co-operation across both countries, Robin and Schubert (2013) interpreted the difference between the two countries as a result of the more diffusion-oriented German science policy. In effect, national and institutional support systems, structures and incentives play important role in promoting research collaboration for growth and development purposes.

\section{Essentials of research collaboration}

In order to stimulate fruitful research collaboration, an enabling environment which offers the necessary national and institutional structures, systems and incentives must exist. The theory of economic development (Schumpeter 1983) and the knowledge spillover theory of entrepreneurship (Acs et al. 2009) point to systemic factors such as fiscal discipline, availability of human capital in the form of researchers and entrepreneurs, investment in research and development, productive credit and lesser administrative and regulatory burdens on economic actors, as factors that encourage fruitful collaboration.

Consequently, in the knowledge-based economy, great investments are made in research, innovation and human and social capital since these elements of the knowledge-based economy are crucial to the effective and efficient conduct of research collaboration for national development (Etzkowitz 2003; Rinne and Koivula 2005). For instance, Horizon 2020, the largest research and innovation programme of the European Union, was launched in December 2013 with over 80 million Euros 
funding (Cunningham and Link 2015). One of the primary objectives of the programme is to reform national and regional $\mathrm{R} \& \mathrm{D}$ and innovation systems to foster excellence and smart specialisation and to reinforce co-operation between universities, research institutes and businesses (Cunningham and Link 2015).

Furthermore, at the level of individual collaborating parties, a fundamental or supporting premise of collaboration can be located within the network theory of social capital (Lin 1999, 2008). Lin $(1999,2008)$ argues that actors will collaborate as a means of consolidating or acquiring resources to facilitate the pursuit of individual or collective goals, implying that the decision to collaborate is a planned one. But as Pearson and Hamilton (2014) articulate in the theory of planned behaviour, the decision is dependent upon attitudes towards the behaviour, perceived behavioural control, subjective norms and environmental possibilities. For example, research collaboration has been found to be critical to the pooling together of the requisite resources and support and serves as a pedestal for ensuring that the right knowledge is produced and used in innovation (Bozeman and Gaughan 2007; Perkmann and Walsh 2009). An investigation into the impact of grants and contracts on academic researchers' interaction with industry in the USA, by Bozeman and Gaughan (2007), showed that funding in the form of grants and contracts from industry had significant effect on academics' propensity to work with industry. Perkmann and Walsh's (2009) investigation into the two sides of collaboration indicated that applied projects showed higher degrees of partner interdependence and enabled exploratory learning by academics, leading to new ideas and projects.

Another essential of research collaboration is the need to build trust and bridge entrenched divides between actors. This is well articulated by Lin (1999) in the network theory of social capital. According the theory, structural and positional variations and collective assets, such as trust and common ideology, are important since they affect the degree to which social relations thrive and yield fruitful results. Kwon and Adler (2014) argue that norms and values constitute the content of social relations and act as a motivational force for achieving collective goals by persons from different sectors of an economy. In a similar vein, Yang et al. (2014), on the basis of findings of an empirical study, argue that trust and shared norms could be beneficial to exploration alliances because these collective assets are critical to uncertain projects involving intensive exchange of tacit knowledge and a higher level of collaboration as well as when rights and obligations are not well outlined.

The important role of trust in research collaboration implies relegation of the concept of ivory tower or place of disengagement since evidence-based practice of entrepreneurship requires effective communication of research findings to knowledge users (Steffens et al. 2014). Rinne and Koivula (2005) enumerate university characteristics such as making a distinction between theory and practice, elitism and an emphasis on autonomy as a tendency towards an ivory tower institution. But they and Martin and Etzkowitz (2000) note that the ivory tower is phasing out as demands and expectations pour in from students, the work environment and the state, thus enabling collaboration between academia and other key actors in the knowledge-based economy.

Regarding the need to have a common ideology, research type becomes very critical to research collaboration. Through the quadrant model of scientific research, alternatively known as the Stokes' quadrant (Stokes 1997), related studies, such as those by 
Baba et al. (2009) and Hughes and Kitson (2012), have established the existence of common research-related philosophical beliefs and needs between academic researchers and knowledge users, who collaborate for the generation of the requisite knowledge for innovation. Generally, basic, applied and use-inspired basic research contribute to innovation in varying degrees (Griliches 1985; Robin and Schubert 2013).

Because basic research has the principal goal of knowledge creation for advancing science, it is often the preoccupation of university researchers while industry is usually interested in applied research due to the focus on application to problem solving or innovation (Bentley et al. 2015). With the general inclination of academic researchers towards advancing their scientific field as against gains in innovation by industry players, use-inspired basic research has been found to be the subject of collaboration in several forms of university-industry research collaboration, for example, as found in studies by (Perkmann and Walsh 2009) and Bentley et al. (2015). The varied interests in relation to research type does not preclude the capacity of basic research as a focus of collaboration between industry and academia and its capacity to eventually yield technological innovations (Moore et al. 2010; Rosenberg and Nelson 1994).

The foregoing discussions suggest that research collaboration while useful and desirable does not occur as a happenstance. It requires deliberate actions that must be guided by a framework of interconnected motivations, intentions, dynamics and expectations.

\section{Suggested conceptual framework for research collaboration towards a knowledge-based economy}

Different researchers and different decision-makers who are confronted with similar issues or phenomena may opt to address them differently. While they may all be guided by the same or similar theoretical explanations, their different experiences, as postulated by Imenda (2014), can shape how they formulate the problems, structure the investigation and attach meanings to the findings. These descriptions can be contextualised to research collaboration.

Such contextualisation will facilitate a comprehensive understanding of research collaboration, which is critical to the design of appropriate interventions in support of research collaboration towards a growth and development-oriented knowledge-based economy. The convictions and experiences of all major players in the collaboration will be indispensable to policy formulation and implementation. Consequently, the conceptual framework of research collaboration towards a knowledge-based economy, as proposed in Fig. 1, seeks to communicate three key issues from the perspective of the university, specifically academic researchers who have the primary responsibility of knowledge production, with particular emphasis on research.

Firstly, in line with the theory of planned behaviour (Ajzen 1991), it is proposed that attitude towards research collaboration, perceived behavioural control over research collaboration, subjective norm on research collaboration and environmental possibility for research collaboration could influence the intentions of academic researchers to engage in research collaboration (Fig. 1). According to Ajzen (1991), intention to perform a particular behaviour is a strong predictor of actual behaviour, so understanding the intentions and associated determinants is, therefore, imperative to decision-making and the design and implementation of informed interventions in support of planned 


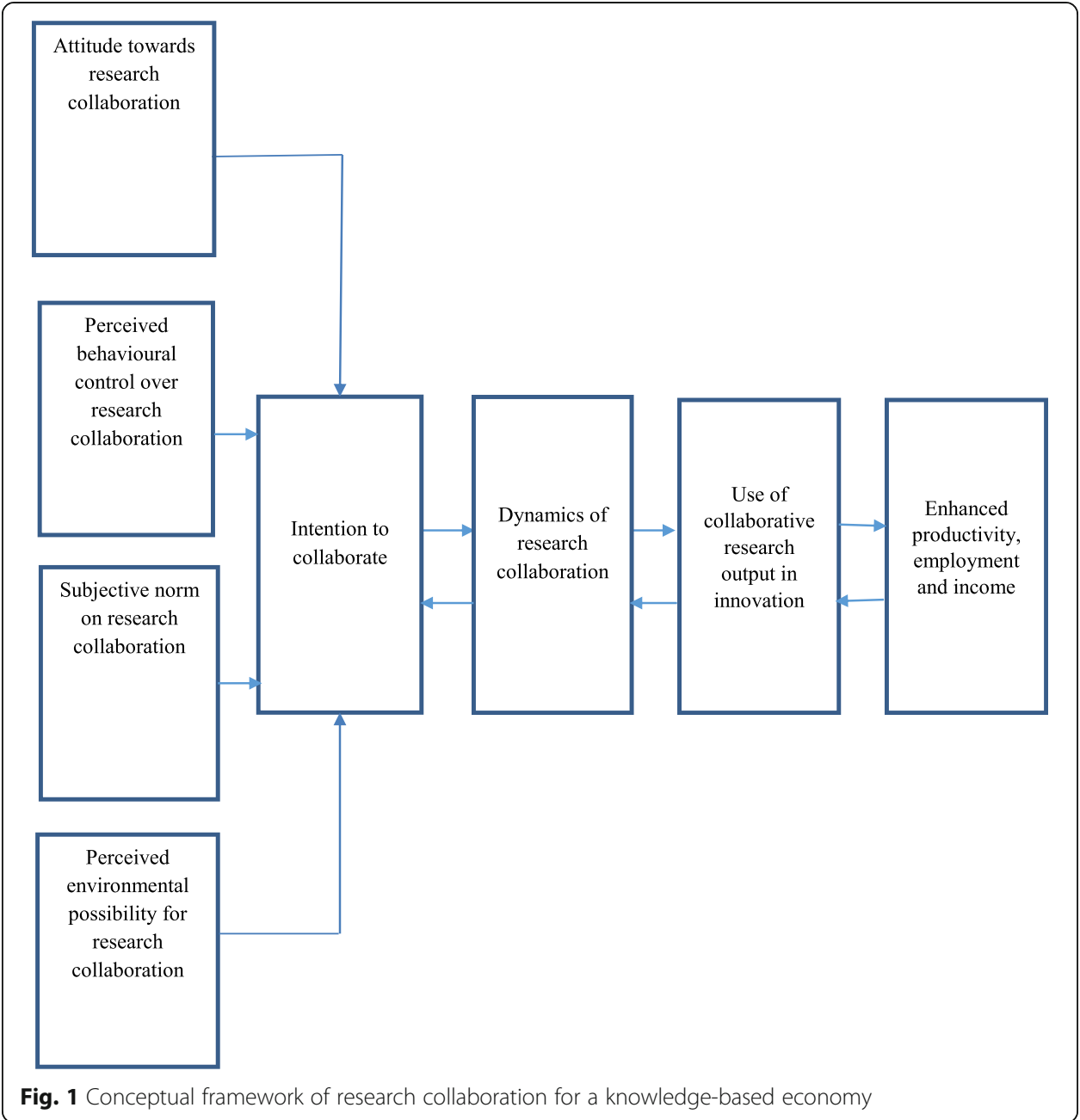

activities. Previous studies present a plethora of factors that could influence the extent to which actors engage in research collaboration. For instance, Leahey (2016) identifies resource constraints, policy pushes, specialisation and the proliferation of information communication technology as some of the drivers of research collaboration, while $\mathrm{Hu}$ et al. (2016) analyse leadership, incentives or reward system, resource capability, external networks and reputation as possible determinants of university-industry collaboration.

From the proposed conceptual framework, factors such as benefits to one's professional career and improved reputation could be studied as part of the broad construct of attitude, defined in the theory of planned behaviour as the degree to which a person has a favourable or unfavourable evaluation of a given behaviour in relation to desired opportunities such as advancement and pleasure (Kautonen et al. 2013). Perceived behavioural control which constitutes the perceived ease or difficulty of performing a given behaviour could comprise the possession and ability to apply the relevant research and related skills and boundary spanning skills for successful research collaboration (Hughes et al. 2011; Hughes and Kitson 2012).

We also propose that expectations from significant others, such as leadership and peers, to engage in research collaboration can be studied as indicators of subjective 
norm on research collaboration. Subjective norm comprises the perceived social pressure to perform or not to perform a given behaviour (Ajzen and Klobas 2013). Background factors such as resources, rewards and other incentives, infrastructure and availability of capable collaborating partners and carriers of innovation constitute critical environmental factors that could collectively or individually serve as determinants of research collaboration (Leahey 2016; Hu et al. 2016).

Secondly, the conceptual framework (Fig. 1) proposes that examination of past collaborative research experiences, captioned as dynamics of research collaboration, is essential to the advancement of the knowledge-based economy. Specifically, assessment of the dynamics of research collaboration, within the framework of the network theory of social capital (Lin 1999, 2008), the quadrant model of scientific research (Stokes 1997) and the theory of economic development (Schumpeter 1983), is critical to decision-making on strategies for promoting collaborative research that yield the requisite knowledge for the development of competitive innovations.

The rationale is that there are some critical issues, from past experiences (Imenda 2014) , which could promote or discourage future research collaboration and subsequent use of the collaborative research findings in innovation. The issues include the extent to which academics engage in research collaboration, parties/sectors with whom academic researchers collaborate, the fundamentals of research collaboration, type of research/ research orientation of academics vis à vis the knowledge requirements of users, type of research collaboration, type of research project, purpose of collaboration, and impact and challenges of the collaboration (Baba et al. 2009; Hughes and Kitson 2012; Leahey 2016).

Thirdly, an understanding of the use of collaborative research findings in innovation is necessary for the design of the right interventions in support of research and innovation in critical sectors of an economy. The analysis could be approached on the basis of Schumpeter's (1983) classification of innovation and abridged versions including product (goods and services), process, technological, organisational or administrative and market or opportunity-related innovations as used by researchers such as Gunday et al. (2011) and Galindo and Méndez (2014).

Fourthly, the interactive and purposive nature of research collaboration signifies the use of social capital in networks for specific outcomes (Hughes et al. 2011; Lin 2008). However, the network theory of social capital (Lin 1999, 2008) posits that variations could occur in social capital due to differences in collective assets and especially differences in the structure and position of network actors. The implication is that intention to collaborate and some dynamics of research collaboration (for example, frequency of collaboration) could significantly differ among academics from various academic disciplines, if substantial differences exist, for example, in the determinants of the intention to collaborate, respectively.

Within the framework of the theory of planned behaviour (Kautonen et al. 2013; Pearson and Hamilton 2014), intention is expected to influence actual behaviour, as illustrated in Fig. 1. Other possible relationships constitute feedback loops from the use of collaborative research findings in innovation back to intention to collaborate (Galindo and Méndez 2014; McCabe et al. 2016). Recognising knowledge diffusion as an important part of the innovation process, Galindo and Méndez (2014) established, through a Schumpeterian model, that innovation and entrepreneurship share positive 
relationship with economic growth leading to a circular effect with all the three variables exerting positive effects on each other. They, therefore, concluded that greater entrepreneurship activity and innovation would enhance economic activity, and the latter would in turn have positive effects on innovation and entrepreneurship.

At the micro-economic level, McCabe et al. (2016) examined feedback effects in an investigation into the ceiling to coproduction in university-industry research collaboration. In their investigation, McCabe et al. (2016) recounted how industry partners in a research collaboration project, on the basis of detailed research reports from their university counterparts, would request the university researchers to conduct further research/analysis of issues of interest. The feedback loops conform to recursive interactions (Etzkowitz 2003; Etzkowitz and Leydesdorff 2000) in the knowledge-based economy, whereby experiences from forward linkages could inform backward linkages and future research.

\section{Empirical considerations}

In the face of increasing demand on researchers in the field to carry out more empirical research (Leahey 2016), we suggest an explanatory mixed methods design for studying issues that have been presented in the proposed conceptual framework. The recommended design is considered appropriate for confirming the findings of previous exploratory studies while making room for gaining additional insights in this emerging field of inquiry. From a methodological point of view, measurement of variables of intention-based and behavioural studies should be carried out following particular rules and guidelines. Admittedly, the proposed conceptual framework, which is yet to be wholly tested, is highly informed by the theory of planned behaviour.

As a result, related research must be implemented, partly, in line with the rules and guidelines of the theory. One basic guideline is that behaviour should be defined and measured according to the target, action, context and time span. In addition, each construct variable or factor should be assessed with several measures. For example, intention to engage in research collaboration can be operationalised with the theory's proposed variables of intention, namely 'intend to', 'will try to' and 'plan to' (Ajzen 2002), which can be transposed into intend to collaborate, will collaborate and plan to collaborate. The theory further recommends the use of double items in assessing each belief-based measure to capture belief strength on one hand and outcome evaluation or motivation to comply or belief control power on the other hand, advisedly, on a semantic differential rating scale (Ajzen and Klobas 2013; Pearson and Hamilton 2014). The rationale behind the latter recommendation, as explained by Ajzen(2002) is that 'belief strength and outcome evaluations for the different accessible beliefs provide substantive information about the attitudinal considerations that guide people's decisions to engage or not to engage in the behaviour under consideration' (p. 9).

Specifically, the theory of planned behaviour illustrates that intention to engage in a given behaviour is dependent upon attitude towards the behaviour, perceived behavioural control, subjective norm and environmental possibilities (Côté et al. 2012). Attitude towards behaviour is regarded as the main predictor of intention in the theory of planned behaviour and constitutes the degree to which a person has a favourable or unfavourable evaluation of a given behaviour in relation to desired opportunities such 
as advancement and pleasure (Kautonen et al. 2013). In a related study of why academics engage with industry, D'Este and Perkmann (2011) found that most academics engaged with industry to, mainly, advance their research work and as a result, recommended policy to focus on a broader range of incentives, besides monetary incentives, for promoting interaction between academia and industry.

Similarly, the network theory of social capital (Lin 1999) postulates that persons engage in social relations, such as research collaboration, to achieve expressive or instrumental purpose in the form of consolidating or acquiring resources that will facilitate the attainment of individual and or collective goals which could also be instrumental or expressive in nature. The additional benefits of collaborating with external parties, including knowledge users, lie in the opportunity to access resources which are embedded in interactions outside one's usual social circles (Fu et al. 2012). This prediction can be likened to the postulate by Ajzen (2011) in his theory of planned behaviour that perceived behavioural control is a predictor of intention to engage in a given behaviour. Perceived behavioural control which connotes the perceived ease or difficulty of performing a given behaviour, can also reflect background factors such as availability of time and resources which, according to the theory of planned behaviour, can be analysed as separate construct variable (Ajjan and Hartshorne 2008; Ajzen 2011). This explains our proposition, in the conceptual framework of this paper, to define background factors to comprise environmental possibility as a possible predictor of academics' intention to engage in research collaboration.

The aforementioned proposition is supported by empirical works on research collaboration which show perceived behavioural control or self-efficacy, in the form of research capabilities and boundary spanning skills, as important variables that can influence the decision of academics to engage in research collaboration with knowledge users. For instance, Banal-Estanõl et al. (2017) analysed university-industry collaboration as an endogenous matching problem and found that the most able and most applied academic researchers prefer to develop collaborative projects, rather than stand alone. In addition, individual level characteristics, in terms of affinity (e.g. preferences for a type of scientific research) and ability (e.g. capacity to produce high-quality scientific output), were more important than institutional characteristics. In related studies by Hughes and Kitson (2012) and Hughes et al. (2011), boundary spanning or relational skills were found to be important to collaboration.

Besides the individual collaborator's perceived behavioural control, the involvement of academics in research collaboration has been found to be influenced by external environmental factors such as availability of time and other resources and incentives such as funding and R \& D infrastructure/equipment (Bozeman and Gaughan 2007; Hughes and Kitson 2012). Nevertheless, there have often been mixed results on the influence of subjective norm on intention. Ajzen (1991) defines subjective norm as perceived social pressure to perform or not to perform a given behaviour. For example, subjective norm/normative belief had significant positive influence on intention in a study of the determinants of nurses' intention to integrate research evidence into clinical decision-making by Côté et al. (2012) and diffusion of innovation by Weigel et al. (2014). However, subjective norm had no significant effect on behavioural intention in a study of faculty decisions to adopt Web 2.0 technologies by Ajjan and Hartshorne (2008). Ajjan and Hartshorne explained their finding to reflect the high degree of 
independence that faculty have when designing their classroom environment. The foregoing discussions show that, analysis of intention to collaborate and its predictors is essential to the design of appropriate interventions for the promotion of research collaboration towards a knowledge-based economy (Ajzen 1991).

\section{Conclusions and policy implications}

Research collaboration between university researchers and the carriers of innovation is increasingly gaining more attention among researchers and policy makers due to its fundamental role in advancing the knowledge-based economy. The upsurge in research on research collaboration and related fields has produced new insights and perspectives that necessitate their careful integration and analysis for effective promotion of the subject matter at the research and policy fronts. This paper has contributed to the substantive issue in a number of ways.

Firstly, on the basis of theoretical and essential discussions, we have highlighted the indispensable role of research collaboration in knowledge production and innovation, and the need for the requisite structures, systems and incentives for the attainment of a knowledge-based economy. Secondly, we have proposed a conceptual framework that takes its key features from the theory of economic development, the knowledge spillover theory of entrepreneurship, the network theory of social capital and the theory of planned behaviour, as well as conceptual papers and empirical studies on research collaboration. This framework should take into account the actors' experiences, since such experiences shape their understanding of the phenomena of interest and their level of motivation.

It is, therefore, deemed important that officials of an economy who seek to drive economic growth and development, through research collaboration, must promote policy interventions designed on the basis of a clear understanding of the determinants and dynamics of research collaboration as well as the use of collaborative research findings in innovation. In doing that, however, they must take into account the experiences of the potential collaborators since these are likely to guide the arrangements or agreements which, in turn, can impact eventual outcomes of collaborations.

\section{Additional file}

Additional file 1: Translation of the abstract into Arabic. (PDF $321 \mathrm{~kb}$ )

Abbreviations

R \& D: Research and development

Funding

The research was supported by the Association of African Universities (AAU) through the award of small grants for theses and dissertations, in the year 2015 .

Authors' contributions

MSBM conceptualised and developed the paper while FE-K contributed to the development of the entire paper, particularly the conceptual framework and the conclusions and policy implications. Both authors read and approved the final manuscript.

Competing interests

Both authors declare that they have no competing interests.

Publisher's Note

Springer Nature remains neutral with regard to jurisdictional claims in published maps and institutional affiliations. 


\section{Author details}

${ }^{1}$ Centre for Entrepreneurship and Small Enterprise Development (CESED), School of Business, College of Humanities and Legal Studies, University of Cape Coast, Cape Coast, Ghana. ${ }^{2}$ Institute for Development Studies (IDS), Faculty of Social Sciences, College of Humanities and Legal Studies, University of Cape Coast, Cape Coast, Ghana.

Received: 14 September 2017 Accepted: 14 March 2018

Published online: 03 April 2018

\section{References}

Acs ZJ, Audretsch DB, Lehmann EE (2013) The knowledge spillover theory of entrepreneurship. Small Bus Econ 41:757-773. https://doi.org/10.1007/11187-013-9505-9

Acs Z, Braunerhjelm P, Audretsch BD, Carlsson B (2009) The knowledge spillover theory of entrepreneurship. Small Bus Econ 32:15-30. https://doi.org/10.1007/s11187-008-9157-3

Afonso O, Monteiro S, Thompson M (2012) A growth model for the quadruple helix. J Bus Econ Manag 13(5):849-865.

Ajjan H, Hartshorne R (2008) Investigating faculty decisions to adopt Web 2.0 technologies: theory and empirical tests. Internet High Educ 11(2):71-80

Ajzen I (1991) The theory of planned behavior. Organ Behav Hum Decis Process 50(2):179-211

Ajzen I (2002) Constructing a TPB questionnaire: conceptual and methodological considerations. http://chuang.epage. au.edu.tw/ezfiles/168/1168/attach/20/pta_41176 7688352 57138.pdf. Accessed 30 Nov 2012.

Ajzen I (2011) The theory of planned behaviour: reactions and reflections. Psychol Health 26(9):1113-1127.

Ajzen I, Klobas J (2013) Fertility intentions: an approach based on the theory of planned behavior. Demogr Res 29(8): 203-232. https://doi.org/10.4054/DemRes.2013.29.8

Baba Y, Shichijo N, Sedita SR (2009) How do collaborations with universities affect firm's innovative performance? The role of "Pasteur scientists" in the advanced materials fields. Res Policy 38:756-764. https://doi.org/10.1016/j.respol. 2009.01.006

Banal-Estañol A, Macho-Stadler I, Pérez-Castrillo D (2017) Endogenous Matching in University-Industry Collaboration: Theory and Empirical Evidence from the United Kingdom. Manag Sci.

Barringer BR, Ireland RD (2008) Entrepreneurship: successfully launching new ventures, 2nd edn. Pearson Education Inc Upper Saddle River

Belderbos R, Carree M, Lokshin B, Sastre JF (2015) Inter-temporal patterns of R \& D collaboration and innovative performance. J Technol Transf 40(1):123-137

Bellotti E, Kronegger L, Guadalupi L (2016) The evolution of research collaboration within and across disciplines in Italian Academia. Scientometrics 109(2):783-811

Bentley PJ, Gulbrandsen M, Kyvik S (2015) The relationship between basic and applied research in universities. High Educ 70(4):689-709

Bergé LR (2017) Network proximity in the geography of research collaboration. Pap Reg Sci 96(4):785-815

Block JH, Thurik R, Zhou H (2013) What turns knowledge into innovative products? The role of entrepreneurship and knowledge spillovers. J Evol Econ 23(4):693-718. https://doi.org/10.1007/s00191-012-0265-5

Borden LM, Perkins DF (1999) Assessing your collaboration: A self-evaluation tool. J Ext 37(2):67-72.

Bozeman B, Gaughan M (2007) Impacts of grants and contracts on academic researchers' interactions with industry. Res Policy 36(5):694-707. https://doi.org/10.1016/j.respol. 2007.01.007

Braunerhjelm P, Acs ZJ, Audretsch BD, Carlsson B (2010) The missing link: knowledge diffusion and entrepreneurship in endogenous growth. Small Bus Econ 34:105-125. https://doi.org/10.1007/s11187-009-9235-1

Cheah S, Yu C (2016) Assessing economic impact of research and innovation originating from public research institutions and universities_case of Singapore PRIs. Triple Helix 3(1):6-36. https://doi.org/10.1186/s40604-016-0037-6

Cooke P, Leydesdorff $L$ (2006) Regional development in the knowledge-based economy: the construction of advantage. J Technol Transf 31(1):5-15

Côté F, Gagnon J, Houme PK, Abdeljelil AB, Gagnon MP (2012) Using the theory of planned behaviour to predict nurses' intention to integrate research evidence into clinical decision-making. J Adv Nurs 68(10):2289-2298. https://doi.org/10.1111/j.1365-2648.2011.05922.x

Cunningham JA, Link AN (2015) Fostering university-industry R \& D collaborations in European Union countries. Int Entrep Manag J 11(4):849-860

D'Este P, Perkmann M (2011) Why do academics engage with industry? The entrepreneurial university and individual motivations. J Technol Transf 36(3):316-339. https://doi.org/10.1007/s10961-010-9153-z

Davenport S, Grimes C, Davies J (1998) Research collaboration and behavioural additionality: a New Zealand case study. Tech Anal Strat Manag 10(1):55-68

Etzkowitz H (2003) Research groups as 'quasi-firms': the invention of the entrepreneurial university. Res Policy 32:109-121

Etzkowitz H, Leydesdorff L (1995) The triple helix-university-industry-government relations: a laboratory for knowledge based economic development. EASST Review 14(1):14-19

Etzkowitz H, Leydesdorff $L$ (2000) The dynamics of innovation: from national systems and "mode 2" to a triple helix of university-industry-government relations. Res Policy 29:109-123

Fu Feng, Nowak MA, Christakis NA, Fowler JH (2012) The Evolution of Homophily. Sci Rep 2(1).

Galindo MÁ, Méndez MT (2014) Entrepreneurship, economic growth, and innovation: are feedback effects at work? J Bus Res 67(5):825-829

Gray B (1985) Conditions facilitating interorganizational collaboration. Hum Relat 38(10):911-936

Griliches Z (1985) Productivity, R \& D, and basic research at the firm level in the 1970s. NBER working paper no. 1547, National Bureau of Economic Research, Cambridge. http://www.nber.org/chapters/c8342.pdf. Accessed 14 Oct 2014

Gunday G, Ulusoy G, Kilic K, Alpkan L (2011) Effects of innovation types on firm performance. Int J Prod Econ 133(2): 662-676

Hu MC, Hung SC, Lo HC, Tseng YC (2016) Determinants of university-industry research collaborations in Taiwan: the case of the National Tsing Hua University. Res Eval 52(2):121-135 
Hughes A, Kitson M (2012) Pathways to impact and the strategic role of universities: new evidence on the breadth and depth of university knowledge exchange in the UK and the factors constraining its development. Camb J Econ 36(3):723-750

Hughes A, Kitson M, Probert J, Bullock A, Milner I (2011) Hidden connections: knowledge exchange between the arts and humanities and the private, public and third sectors. Centre for Business Research, University of Cambridge, Cambridge

Imenda S (2014) Is there a conceptual difference between theoretical and conceptual frameworks? Grad J Soc Sci 38(2):185-195 Johnson B, Lorenz E, Lundvall BÅ (2002) Why all this fuss about codified and tacit knowledge? Ind Corp Chang 11(2):245-262 Karnani F (2013) The university's unknown knowledge: tacit knowledge, technology transfer and university spin-offs findings from an empirical study based on the theory of knowledge. J Technol Transf 38(3):235-250. https://doi. org/10.1007/s10961-012-9251-1

Kautonen T, Van Gelderen M, Tornikoski ET (2013) Predicting entrepreneurial behaviour: a test of the theory of planned behaviour. Appl Econ 45(6):697-707

Kwon SW, Adler PS (2014) Social capital: maturation of a field of research. Acad Manag Rev 39(4):412-422

Leahey E (2016) From sole investigator to team scientist: trends in the practice and study of research collaboration. Annu Rev Sociol 42:81-100

Lee SL (2000) The sustainability of university-industry research collaboration: an empirical assessment. J Technol Transfer 25:111-133

Leydesdorff $L$ (2010) The knowledge-based economy and the triple helix model. Ann Rev Infn Sci Tech 44(1):365-417

Leydesdorff $L$ (2012) The triple helix, quadruple helix,.., and an N-tuple of helices: explanatory models for analyzing the knowledge-based economy? J Knowl Econ 3(1):25-35 doi: 201110.1007/s13132-011-0049-4

Lin N (1999) Building a network theory of social capital. Connect 22(1):28-51

Lin N (2008) A network theory of social capital. In: Castiglione D, van Deth J, Wolleb G (eds) The handbook of social capital. Oxford University Press, Oxford, pp 50-69

Martin H, Etzkowitz H (2000) The origin and evolution of the university species. SPRU working paper No. 59. Science and Technology Policy Research Unit (SPRU), Brighton. http://citeseerx.ist.psu.edu/viewdoc/download?doi=10.1.1. 599.5719\&rep=rep1\&type=pdf. Accessed 9 April 2013.

Mayer M, Kenter R (2015) The prevailing elements of public-sector collaboration. Advancing Collaboration Theory: Models, Typologies, and Evidence 13:43-64

McCabe A, Parker R, Cox S (2016) The ceiling to coproduction in university-industry research collaboration. High Educ Res Dev 35(3):560-574

McNamara M (2012) Starting to untangle the web of cooperation, coordination, and collaboration: a framework for public managers. Int J Public Admin 35(6):389-401

Melber H (2015) Knowledge is power and power affects knowledge: challenges for research collaboration in and with Africa. Afr Dev 4:21-42

Menya AA, K'Akumu OA (2016) Inter-agency collaboration for fire disaster management in Nairobi City. J Urban Manage 5(1):32-38

Moore B, Hughes A, Ulrichsen T (2010) Synergies and tradeoffs between research, teaching and knowledge exchange. Research Report to HEFCE. Public and Economic Corporate Consultants (PACEC) and the Centre for Business Research (CBR), Cambridge. http://www.pacec.co.uk/wpcontent/uploads/2010/09/Synergies_and_Tradeoffs_ Between_Research_Teaching_and_Knowledge_Exchange.pdf. Accessed 14 Mar 2013.

Nissen HA, Eald MR, Clarke AH (2014) Knowledge sharing in heterogeneous teams through collaboration and cooperation: exemplified through public-private-innovation partnerships. Ind Mark Manag 43(3):473-482

Nyaga GN, Lynch DF, Marshall D, Ambrose E (2013) Power asymmetry, adaptation and collaboration in dyadic relationships involving a powerful partner. J Supply Chain Manag 49(3):42-65

Park HW, Leydesdorff L (2010) Longitudinal trends in networks of university-industry-government relations in South Korea: the role of programmatic incentives. Res Policy 39(5):640-649

Pearson M, Hamilton K (2014) Investigating driver willingness to drive through flooded waterways. Accid Anal Prev 72 : 382-390. https://doi.org/10.1016/j.aap.2014.07.018

Perkmann M, Walsh K (2009) The two faces of collaboration: impacts of university-industry relations on public research. Ind Corp Chang 18(6):1033-1065. https://doi.org/10.1093/icc/dtp015

Rinne R, Koivula J (2005) The changing place of the university and a clash of values. The entrepreneurial university in the European knowledge society a review of the literature. Higher Educ Managet Policy 17(3):91-123

Robin S, Schubert T (2013) Cooperation with public research institutions and success in innovation: evidence from France and Germany. Res Policy 42:149-166

Rosenberg N, Nelson RR (1994) American universities and technical advance in industry. Res Policy 23(3):323-348

Schumpeter JA (1983) The theory of economic development. Transaction publishers, Brunswick, New Jersey. German edition: Schumpeter JA (1983) Theorie der wirtschaftlichen entwicklung (trans: Opie R, New Intro: Elliott JE). Harvard University, Cambridge

Steffens PR, Weeks CS, Davidsson P, Isaak L (2014) Shouting from the ivory tower: a marketing approach to improve communication of academic research to entrepreneurs. Enterp Theory Pract 38(2):399-426. https:// doi.org/10.1111/etap.12079

Stokes DE (1997) Pasteur's quadrant: basic science and technological innovation. Brookings Institution Press, Washington, DC

Teirlinck P, Spithoven A (2013) Research collaboration and R \& D outsourcing: different R \& D personnel requirements in SMEs. Technovation 33(4):142-153

Weigel FK, Hazen BT, Cegielski CG, Hall DJ (2014) Diffusion of innovations and the theory of planned behavior in information systems research: a metaanalysis. CAIS 34:31

Yang H, Zheng Y, Zhao X (2014) Exploration or exploitation? Small firms' alliance strategies with large firms. Strateg Manag J 35(1):146-157. https://doi.org/10.1002/smj.2082 